\title{
MANAJEMEN EKSTRAKURIKULER MADRASAH
}

\section{Qiqi Yuliati Zakiyah}

Universitas Islam Negeri Sunan Gunung Djati Bandung JI. A.H. Nasution No. 105, Cibiru Bandung, Jawa Barat, 40614

Email: qiqiyuliati@uinsgd.ac.id

\section{Ipit Saripatul Munawaroh}

Universitas Islam Negeri Sunan Gunung Djati Bandung

Jl. A.H. Nasution No. 105, Cibiru Bandung, Jawa Barat, 40614

Email: phitiphit22@gmail.com

\begin{abstract}
ABSTRAK
Ekstrakurikuler merupakan kegiatan yang dilakukan di luar jam pelajaran yang harus dikembangkan dengan baik oleh sebuah madrasah, supaya minat, bakat, dan potensi peserta didik dapat dikembangkan secara lebih optimal. Dalam pelaksanaannya diperlukan fungsi-fungsi manajemen yaitu perencanaan, pelaksanaan, serta evaluasi agar kegiatan ekstrakurikuler berjalan efektif. Pendekatan yang digunakan dalam penelitian ini adalah kualitatif dengan metode deskriptif. Hasil penelitian manajemen ekstrakurikuler di MAN Model Cipasung, yakni: 1) Perencanaan ekstrakurikuler dilaksanakan setiap awal tahun pembelajaran meliputi: penentuan tujuan ekstrakurikuler, jenis kegiatan ekstrakurikuler, jadwal kegiatan, dan pelatih ekstrakurikuler. 2) Pelaksanaan ekstrakurikuler meliputi: langkah-langkah pelaksanaan kegiatan ekstrakurikuler, pengkondisian peserta didik, serta partisipasi peserta didik dalam mengikuti ekstrakurikuler. 3) Evaluasi kegiatan ekstrakurikuler dapat dijadikan dasar pertimbangan lahirnya kebijakan tentang tindak lanjut program, evaluasi yang dilakukan meliputi evaluasi secara intern dan juga evaluasi secara eksternal yang dilaksanakan setiap awal tahun ajaran baru. 4) Hasil yang dicapai dalam pelaksanaan ekstrakurikuler di MAN Model Cipasung adalah berkembangnya bakat peserta didik baik dalam bidang akademik maupun nonakademik.
\end{abstract}

Kata kunci: manajemen, ekstrakurikuler, madrasah

\section{ABSTRACT}

Extracurricular activities are performed outside the lesson hours that must be developed properly by a madrasah, so that interest, talent, and potential learners can be developed more optimally. In order to extracurricular activities can be run effectively then in the implementation required management functions of planning, implementation, and evaluation of extracurricular activities. The approach used in this research is qualitative with descriptive 
method. The results of extracurricular management research at MAN Model Cipasung, namely: 1) Extracurricular planning carried out every at the beginning of each learning year include: determination of extracurricular goals, types of extracurricular activities, activity schedules, and extracurricular trainers. 2) Extracurricular implementation includes: steps of execution of extracurricular activities, conditioning of learners, and participation of learners in following extracurricular. 3) Evaluation of extracurricular activities can be used as a basis for consideration of the policy regarding follow-up of the program, the evaluation includes internal evaluation as well as external evaluation conducted at the beginning of the new school year. 4) The results achieved in the implementation of extracurricular in MAN Model Cipasung is the development of talent learners in both academic and non academic.

Keywords: management, extracurricular activities, islamic school

\section{PENDAHULUAN}

Manajemen peserta didik sebagai layanan yang memusatkan perhatian pada pengaturan, pengawasan, dan layanan siswa di kelas dan di luar kelas seperti: pengenalan, pendaftaran, layanan individual seperti pengembangan kesuluruhan kemampuan, minat, kebutuhan sampai ia matang di sekolah (Prihatin, 2014, h. 4). Sobry Sutikno (2009, h. 62) dalam pengelolaan kesiswaan terdapat empat prinsip dasar, yang salah satunya adalah kondisi siswa sangat beragam, ditinjau dari kondisi fisik, kemampuan intelektual, sosial ekonomi, minat dan seterusnya. Oleh karena itu diperlukan wahana kegiatan yang beragam, sehingga setiap siswa memiliki wahana untuk berkembang secara optimal. Berprinsip pada hal tersebut, maka suatu madrasah akan terus mengembangkan potensi, minat, dan bakat yang dimiliki oleh peserta didik. Madrasah bisa memberikan kesempatan bagi peserta didik untuk mengikuti kegiatan ekstrakurikuler untuk mengembangkan potensi, minat, dan bakat mereka.

UU No. 20 Tahun 2003 mengatakan bahwa hak setiap peserta didik yaitu harus mendapat perlakuan sesuai dengan bakat, minat, dan kemampuannya. Hal tersebut dapat diwujudkan melalui kegiatan ekstrakurikuler baik yang sifatnya wajib maupun pilihan yang disediakan oleh setiap madrasah.

Peran MAN Model Cipasung dalam upaya mengembangkan minat dan bakat peserta didiknya ditandai dengan adanya wadah ekstrakurikuler yang beragam yakni terdapat 20 kegiatan ekstrakurikuler sebagai wadah untuk mengembangkan potensi peserta didik dengan menyadari bahwa setiap peserta didik mempunyai potensi, minat, dan bakat yang berbeda, tugas pendidikan adalah untuk mengembangkan peserta didik sesuai dengan potensi, minat, dan bakat masing-masing. Atas alasan itulah MAN Model Cipasung menyediakan wadah ekstrakurikuler yang beragam. Dalam upaya meningkatkan potensi, minat, dan bakat setiap peserta didik di MAN Model Cipasung Tasikmalaya diwajibkan untuk mengikuti kegiatan ekstrakurikuler baik ekstrakurikuler yang sifatnya wajib maupun pilihan.

\section{KAJIAN TEORI}

Manajemen menurut Malayu Hasibuan (2006, h. 2) adalah aktivitasaktivitas perencanaan, pengorganisasian, pengendalian, penempatan, 
pengarahan, pemotivasian, komunikasi, dan pengambilan keputusan yang dilakukan oleh setiap organisasi dengan tujuan untuk mengkoordinasikan berbagai sumber daya yang dimiliki oleh perusahaan sehingga akan dihasilkan suatu produk atau jasa secara efisien.

Permendikbud RI No. 81A Tahun 2013 mendefinisikan bahwa ekstrakurikuler adalah kegiatan pendidikan yang dilakukan oleh peserta didik di luar jam belajar kurikulum standar sebagai perluasan dari kegiatan kurikulum dan dilakukan di bawah bimbingan sekolah dengan tujuan untuk mengembangkan kepribadian, bakat, minat, dan kemampuan peserta didik yang lebih luas atau di luar jam minat yang dikembangkan oleh kurikulum.

Kata "madrasah" berasal dari Bahasa Arab yang merupakan bentuk kata keterangan tempat (zharaf makan) dari akar kata "darasa". Secara harfiyah "madrasah" diartikan sebagai tempat belajarnya para pelajar atau tempat untuk memberikan pelajaran. Selain itu, dari kata "darasa" juga bisa diturunkan kata "midras" yang mempunyai arti buku yang dipelajari atau tempat belajar. Madrasah adalah lembaga pendidikan tingkat dasar dan menengah, baik yang mengajarkan ilmu agama Islam saja, perpaduan antara ilmu agama Islam dan ilmu umum, maupun ilmu-ilmu umum yang berbasis ajaran Islam (Asmani, 2013, h. 19).

Manajemen ekstrakurikuler menurut Mulyono (2008, h. 198) adalah seluruh proses yang direncanakan dan diusahakan secara terorganisasi mengenai kegiatan sekolah yang dilakukan di luar kelas dan di luar jam pelajaran (kurikulum) untuk menumbuhkembangkan potensi sumber daya manusia (SDM) yang dimiliki peserta didik, baik berkaitan dengan aplikasi ilmu pengetahuan yang didapatkannya maupun dalam pengertian khusus untuk membimbing peserta didik dalam mengembangkan potensi dan bakat yang ada dalam dirinya melalui kegiatan-kegiatan yang wajib maupun pilihan.

Dengan adanya manajemen ekstrakurikuler, kegiatan ekstrakurikuler

dapat sesuai dengan tujuan yang diharapkan. Dalam manajemen ekstrakurikuler madrasah dapat diterapkan fungsi-fungsi manajemen secara umum, yang paling sederhana adalah fungsi manajemen menurut Engkoswara yakni perencanaan, pelaksanaan, dan evaluasi.

Pertama, Sebelum guru ekstrakurikuler membina kegiatan ekstrakurikuler terlebih dahulu merencanakan aktivitas yang akan dilaksanakan. Penyusunan rencangan aktivitas ini dimaksudkan agar guru mempunyai pedoman yang jelas dalam melatih kegiatan ekstrakurikuler. Rancangan ini dibuat setiap semester. Selain bermanfaat bagi guru juga diperlukan oleh kepala sekolah untuk mempermudah dalam mengadakan supervisi (Suryosubroto, 2012, h. 304).

Peraturan Menteri Pendidikan dan Kebudayaan Republik Indonesia Nomor 81A tahun 2013, satuan pendidikan selajutnya menyusun "Panduan Kegiatan Ekstrakurikuler" yang berlaku di satuan pendidikan dan mensosialisasikannya kepada peserta didik pada setiap awal tahun pelajaran. Panduan kegiatan ekstrakurikuler yang diberlakukan pada satuan pendidikan paling tidak memuat: 1) Kebijakan mengenai kegiatan ekstrakurikuler: 2) Rasional dan tujuan kebijakan ekstrakurikuler, 3) Deskripsi program ekstrakurikuler meliputi: ragam kegiatan ekstrakurikuler yang disediakan, tujuan dan kegunaan ekstrakurikuler, keanggotaan dan persyaratan, jadwal kegiatan, 
level supervisi yang dilakukan dari orang tua peserta didik. 4) Manajemen program ekstrakurikuler: a) Struktur organisasi pengelolaan program ekstrakurikuler pada satuan pendidikan. b) Level supervisi yang disiapkan oleh satuan pendidikan untuk masing-masing kegiatan ekstrakurikuler. c) Level asuransi yang disiapkan oleh satuan pendidikan untuk masing-masing kegiatan ekstrakurikuler. 5) Pendanaan dan mekanisme pendanaan program ekstrakurikuler.

Berpedoman pada tujuan dan maksud kegiatan ekstrakurikuler di sekolah maka dapat ditetapkan prinsip-prinsip program ekstrakurikuler yang salah satunya adalah diikuti oleh semua peserta didik, guru, dan personel administrasi dalam usaha meningkatkan program.

Kedua, Pelaksanaan program-program kegiatan ekstrakurikuler hendaknya dikendalikan untuk pencapaian tujuan-tujuan yang telah diterapkan dan kontribusinya terhadap perwujudan visi sekolah serta tujuan ekstrakurikuler. Eka Prihatin (2014, h. 169-182) mengemukakan bahwa dari setiap pelaksanaan program kegiatan ekstrakurikuler hendaknya: a) Suasana yang kondusif. b) Tidak terlalu membebani siswa dan tidak merugikan aktivitas kurikuler sekolah. c) Usahakan pelaksanaan kegiatan konsisten sebagaimana terjadwal dan terpublikasikan. d) Kerjasama tim adalah fundamental, hindari pembatasan untuk partisipasi. e) Setiap personel sekolah pada dasarnya bertanggungjawab atas pengembangan program ekstrakurikuler yang diselenggarakan.

Pembinaan kegiatan ekstrakurikuler dapat berbeda-beda antara satu sekolah dengan sekolah yang lain. Sehubungan dengan itu, Amir Dien dikutip Suryosubroto, menjelaskan hal-hal yang perlu diketahui oleh pembina ekstrakurikuler: kegiatan harus dapat meningkatan pengayaan siswa yang beraspek kognitif, afektif, dan psikomotor; memberikan tempat serta penyaluran bakat dan minat sehingga siswa akan terbiasa dengan kesibukan-kesibukan yang bermakna; adanya perencanaan dan persiapan serta pembinaan yang telah diperhitungkan masak-masak sehingga program ekstrakurikuler mencapai tujuan dan; pelaksanaan kegiatan ekstrakurikuler oleh semua atau sebagai siswa.

Partisipasi peserta didik sangat penting dan memengaruhi pelaksanaan kegiatan ekstrakurikuler yang disediakan oleh madrasah. Suryosubroto (2009) berkesimpulan bahwa mengukur partisipasi peserta didik dapat dilihat dari seberapa jauh keterlibatan mereka dalam organisasi di mana mereka menjadi anggotanya. Partisipasi tersebut akan terwujud apabila organisasi memberikan peluang kepada anggotanya untuk berpartisipasi. Peluang tersebut luas dalam organisasi yang bersifat demokratis baik dalam pengambilan keputusan maupun dalam praktik pelaksanaan dan evaluasi hasil pelaksanaan keputusan. Dengan demikian, kegiatan ekstrakurikuler merupakan salah satu organisasi yang memungkinkan anggotanya untuk berpartisipasi penuh.

Ketiga, Evaluasi atau penilaian dalam proses pendidikan menjadi salah satu faktor penting dalam pembelajaran. Evaluasi berfungsi untuk mengukur mutu pendidikan. Dalam UU Nomor 20 Tahun 2003 tentang Sistem Pendidikan Nasional disebutkan bahwa evaluasi pendidikan adalah kegiatan pengendalian, penjaminan, dan penetapan mutu pendidikan terhadap berbagai komponen pendidikan sebagai bentuk pertangungjawaban penyelenggaraan pendidikan. 
Guba dan Lincoln mendefinisikan evaluasi sebagai suatu proses memberikan pertimbangan mengenai nilai dan arti sesuatu yang dipertimbangkan yang bisa berupa orang, benda, kegiatan, keadaan atau sesuatu ketentuan tertentu (Badrudin, 2014, h. 177).

Penilaian perlu diberikan terhadap kinerja peserta didik dalam kegiatan ekstrakurikuler. Kriteria keberhasilan lebih ditentukan oleh proses dan keikutsertaan peserta didik dalam kegiatan ekstrakurikuler yang dipilihnya. Peserta didik diwajibkan untuk mendapatkan nilai memuaskan pada kegiatan ekstrakurikuler wajib pada setiap semester (Permendikbud, 2014, h. 4). Setelah program selesai, pembina perlu mengadakan evaluasi. Evaluasi ini dimaksudkan untuk mengetahui kemanfaatan program bagi peserta didik maupun bagi madrasah. Hasil dari evaluasi ini juga bermanfaat bagi pengambil keputusan untuk menentukan perlu adanya suatu program ekstrakurikuler dilanjutkan.

\section{METODOLOGI}

Penelitian ini menggunakan penelitian kualitatif. Lokasi yang digunakan adalah MAN Model Cipasung Tasikmalaya.

Sumber data meliputi: 1) Wakil Kepala Madrasah Bidang Kesiswaan MAN Model Cipasung, Ahmad Nasa'i, S.Pd. 2)Kepala Madrasah MAN Model Cipasung, Dra. Hj. Ida Nurhalida, M.Pd. 3)Pembina ekstrakurikuler MAN Model Cipasung 4)Sample Peserta didik mewakili masing-masing ekstrakurikuler. Teknik Pengumpulan Data meliputi: 1) Wawancara. 2) Observasi. 3) Dokumentasi.

Analisis data dilakukan dengan kategorisasi data penafsiran data. Adapun uji absah data dilakukan dengan perpanjangan keikutsertaan, ketekunan pengamatan, triangulasi, cek teman sejawat, analisis kasus negatif, kecukupan referensi, uraian rinci dan auditing (Moleong, 2011)

\section{HASIL DAN PEMBAHASAN}

Berdasarkan hasil observasi, wawancara dan dokumentasi yang ada dilapangan kegiatan-kegiatan fungsi manajemen ekstrakurikuler adalah sebagai berikut:

\section{Perencanaan kegiatan ekstrakurikuler di MAN Model Cipasung}

Kegiatan ekstrakurikuler di MAN Model Cipasung dibawahi langsung oleh Wakil Kepala Bidang Kesiswaan yang juga bertindak selaku Koordinator umum kegiatan ekstrakurikuler. Penyusunan rencana kegiatan ekstrakurikuler dilaksanakan pada setiap awal tahun pembelajaran melalui rapat yang dilakukan oleh kepala madrasah, Wakil Kepala Bidang Kesiswaan, dan masingmasing pembina ekstrakurikuler yang ada di MAN Model Cipasung. Tujuan pelaksanaan kegiatan ekstrakurikuler adalah untuk memfasilitasi bakat serta minat peserta didik yang tidak ada dalam intra, agar semua potensi peserta didik bisa dikembangkan.

Ada 20 jenis kegiatan ekstrakurikuler di MAN Model Cipasung, yaitu: rohis dan seni Islami, tahfidzul quran dan kaligrafi, PKS, PMR, paskibra, pramuka, KIR, jurnalistik, kosmik, arabic club, english club, social club, drum 
band, sanggar seni, sanggar teater, tenis meja, bulu tangkis, silat, bela diri karate, volly, dan basket.

Pembina ekstrakurikuler di MAN Model Cipasung sekaligus juga merupakan pelatih pada masing-masing ekstrakurikuler. Ada 18 orang guru yang menjadi pembina ekstrakurikuler sebagai berikut:

Tabel 1

Data Guru Pembina Ekstrakurikuler

\begin{tabular}{|c|l|l|}
\hline NO & \multicolumn{1}{|c|}{ Nama } & Jabatan \\
\hline 1 & Asep Nursyamsi, S.Ag. M. Si. & $\begin{array}{l}\text { Pembina Rohis dan Seni Islami/ } \\
\text { IREMA }\end{array}$ \\
\hline 2 & Solihin & $\begin{array}{l}\text { Pembina Tahfidzul Quran dan } \\
\text { Kaligrafi }\end{array}$ \\
\hline 3 & Heri Ahmad Fauzi, S.Kom. & Pembina BRONIS \\
\hline 4 & Dra. Aat Rahmat Rosidah, M. Si. & Pembina PMR \\
\hline 5 & Abdul Wahab & Pembina Paskibra dan Pramuka \\
\hline 6 & Wahyu T. Aripin, ST. & Pembina English Club \\
\hline 7 & Eneng Mahmudah, S.Pd. M.Pkim. & Pembina Kosmik dan KIR \\
\hline 8 & Delis Rosita Amalia, S.Pd. & Pembina Arabic Club \\
\hline 9 & Hanny Hanifah, SE. & Pembina Social Club \\
\hline 10 & Abdul Wahid, S.Ag. & Pembina Group Drum Band \\
\hline 11 & Abdul Rais Sidik, S. Sen. & Pembina Sanggar Seni \\
\hline 12 & Dian Lugina, S. Sen. & Pembina sanggar Teater \\
\hline 13 & Ujang Badrul, S. Pd. M. Pd. & Pembina Tenis Meja \\
\hline 14 & Drs. Rasyid Ridlo & Pembina Bulu Tangkis \\
\hline 15 & Wandi Kayim Luswandi, S.Pd. & Pembina Silat \\
\hline 16 & lim Husaeri Putera, S.Ag. & Pembina Bela Diri Karate \\
\hline 17 & Cep Roni Sundawa, S.Pd. & Pembina Bola Volly \\
\hline 18 & Rico Nurul Fuad, S.Pd. & Pembina Bola Basket \\
\hline
\end{tabular}

Penyusunan rencana kegiatan ekstrakurikuler di MAN Model Cipasung sudah sesuai dengan apa yang dikemukakan oleh Suryosubroto (2012:304) bahwa sebelum guru ekstrakurikuler membina kegiatan ekstrakurikuler terlebih dahulu merencanakan aktivitas yang akan dilaksanakan. Penyusunan rancangan aktivitas ini dimaksudkan agar guru mempunyai pedoman yang jelas dalam melatih kegiatan ekstrakurikuler. Rancangan ini dibuat setiap semester untuk memudahkan dalam mengadakan supervisi.

Tujuan pelaksanaan kegiatan ekstrakurikuler di MAN Model Cipasung adalah untuk memfasilitasi bakat serta minat peserta didik yang tidak ada dalam intra agar semua potensi peserta didik bisa dikembangkan, sudah sesuai dengan tujuan walaupun masih ada yang perlu ditingkatkan lagi. Tujuan kegiatan ekstrakurikuler tersebut sesuai dengan pendapat Wahjosumidjo bahwa ada tiga hal pokok yang perlu diperhatikan oleh kepala sekolah bahwa kegiatan ekstrakurikuler bertujuan untuk: 1) Memperdalam dan memperluas pengetahuan siswa yang berkaitan dengan mata pelajaran sesuai dengan kurikuler yang ada. Hal ini dapat terwujud melalui kegiatan ekstrakurikuler seperti Social club, Kosmik, Arabic Club, dan English Club. Kegiatan 
ekstrakurikuler tersebut dapat menunjang terhadap proses belajar anak di dalam kelas. 2) Melengkapi upaya pembinaan, pemantapan, dan pembentukan nilai-nilai kepribadia siswa. Kegiatan ini berkaitan dengan semacam usaha mempertebal ketakwaan terhadap Tuhan Yang Maha Esa, latihan kepemimpinan dan sebagainya. Dalam usaha mempertebal ketakwaan terhadap Tuhan yang Maha Esa, hal ini dapat terwujud dengan adanya beberapa ekstrakurikuler keagamaan yang didalamnya terdapat berbagai kegiatan keagamaan. Sedangkan dalam upaya melatih kepemimpinan peserta didik, dapat terwujud dengan adanya ekstrakurikuler kekridaan, seperti: Pramuka, PMR, Paskibraka. 3) Membina dan meningkatkan bakat, minat, dan keterampilan. Kegiatan ini untuk memacu ke arah kemampuan mandiri, percaya diri, dan kreatif. Dalam upaya meningkatkan bakat, minat, dan keterampilan peserta didik di MAN Model Cipasung terdapat berbagai jenis ekstrakurikuler yang dapat dipilih peserta didik sesuai dengan bakat dan juga keinginan mereka.

\section{Pelaksanaan ekstrakurikuler di MAN Model Cipasung Tasikmalaya}

Kebanyakan jadwal ekstrakurikuler dilaksanakan pada hari Jumat karena pada hari tersebut kegiatan pengajian santri di pesantren diliburkan. Hal ini sangat dimungkinkan karena lokasi MAN Model Cipasung berada di lingkungan Pesantren Cipasung, dan dekat pula dengan beberapa pesantren kecil sekitar Pesantren Cipasung, sehingga 95\% peserta didik MAN Model Cipasung tinggal dan menjadi santri di pesantren-pesantren tersebut. Oleh karena itu, penjadwalan kegiatan ekstrakurikuler di MAN Model Cipasung disesuaikan dengan kegiatan mengaji santri di pesantren.

Sebelum kegiatan ekstrakurikuler berlangsung, dilaksanakan apel siang terlebih dahulu khusus untuk hari Jumat. Setelah itu, peserta didik membubarkan diri menuju tempat latihan masing-masing. Sebelum latihan dilakukan, terlebih dahulu dikenalkan materi dan kontrak pembelajaran yang akan dilaksanakan. Keterlibatan dan komunikasi antara pelatih dengan peserta didik terjalin dengan baik. Jika ada peserta didik yang kesulitan melaksanakan intruksi dari pelatih, maka pelatih pun selalu membantunya. Kedekatan antara pelatih dengan peserta didik pun sangat terlihat peserta didik pun tidak merasa canggung untuk bercanda bersama pelatih, akan tetapi mereka tetap menjaga rasa hormatnya kepada pelatih.

Dalam menumbuhkan partisipasi peserta didik adalah dengan cara menumbuhkan ikatan emosional kekeluargaan agar tidak terkesan seperti bos terhadap anak buah, namun seperti kakak dengan adiknya sehingga proses pelaksanaan kegiatan pun lebih menyenangkan. Bahkan ada beberapa alumni yang masih aktif dalam melatih beberapa ekstrakurikuler yang dulu mereka ikuti.

Pelaksanaan kegiatan ekstrakurikuler di madrasah tidak akan terlepas dari beberapa faktor yang memengaruhinya, salah satunya penjadwalan kegiatan ekstrakurikuler. Dalam Pedoman Kegiatan Ekstrakurikuler yang terdapat dalam Permendikbud Nomor 81A tahun 2013 dijelaskan bahwa penjadwalan waktu kegiatan ekstrakurikuler sudah harus dirancang pada awal tahun atau awal semester dan dibawah bimbingan Kepala Madrasah dan Wakil Kepala Bidang Kurikulum dan peserta didik. Jadwal waktu kegiatan 
ekstrakurikuler diatur sedemikian rupa sehingga tidak menghambat pelaksanaan kegiatan kurikuler atau dapat menyebabkan gangguan bagi peserta didik dalam mengikuti kegiatan kurikuler. Oleh sebab itu, pelaksanaan kegiatan ekstrakurikuler di MAN Model Cipasung kebanyakan hari Jumat karena mengikuti jadwal kegiatan pengajian santri di pesantren. Selain hari Jumat, dilaksanakan juga kegiatan ekstrakurikuler setelah kegiatan pembelajaran selesai pada hari yang lain. Pelaksanaan kegiatan ekstrakurikuler di MAN Model Cipasung tidak mengganggu berjalannya pembelajaran, karena ekstrakurikuler hanyalah kegiatan tambahan yang dapat menunjang kegiatan belajar peserta didik di kelas.

Suryosubroto (2009, h. 86) menyimpulkan bahwa mengukur partisipasi peserta didik dapat dilihat dari seberapa jauh keterlibatan mereka dalam organisasi di mana mereka menjadi anggotanya. Kenyataan yang terjadi di MAN Model Cipasung hal ini terlihat dari katerlibatan para senior dan para alumni yang sering melatih anak-anak dalam kegiatan ekstrakurikuler ketika para pembina tidak dapat melatih kegiatan ekstrakurikuler.

\section{Evaluasi ekstrakurikuler di MAN Model Cipasung Tasikmalaya}

Ada dua jenis evaluasi yang dilakukan, yakni evaluasi intern dan juga eksternal. Pada evaluasi secara intern diakukan oleh masing-masing anggota ekstrakurikuler pada tataran kepengurusan organisasi dan pembina ekstrakurikuler yang dilakukan setiap bulan tergantung kebutuhan masingmasing ekstrakurikuler. Secara keseluruhan evaluasi kegiatan ekstrakurikuler MAN Cipasung dilaksanakan setiap awal tahun pembelajaran melalui pelaksanaan rapat yang melibatkan masing-masing pembina ekstrakurikuler untuk menyampaikan setiap kegiatan yang telah dilaksanakan.

Manfaat dilakukannya evaluasi bagi kegiatan ekstrakurikuler sangat berguna untuk mengetahui ekstrakurikuler yang masih aktif maupun tidak aktif lagi karena kurangnya minat peserta didik.

Evaluasi menurut Hikmat (2009, h. 125) adalah menilai semua kegiatan untuk menemukan indikator yang menyebabkan sukses atau gagalnya pencapaian tujuan, sehingga dapat dijadikan bahan kajian berikutnya. Untuk mengetahui tingkat prestasi peserta didik maka hal yang harus dilakukan para pendidik adalah mengevaluasi hasil dari kegiatan mengajar. Misalnya dilaksanakan ulangan, ujian tengah semester, dan ujian akhir. Evaluasi dilakukan salah satunya untuk mengetahui kemampuan minat, dan bakat anak didik dalam bidang studi atau jurusan yang dipilinnya.

Salah satu manfaat diadakannya evaluasi bagi kegiatan ekstrakurikuler adalah untuk mengetahui ekstrakurikuler yang masih aktif maupun tidak aktif lagi. Sebagai contoh, pernah ada salah satu ekstrakurikuler yang dihilangkan, seperti ekstrakurikuler PKS (Patroli Keamanan Siswa) karena ekstrakurikuler tersebut kurang bahkan tidak ada peminatnya diganti dengan ekstrakurikuler lain yang disesuaikan dengan kebutuhan peserta didik. Hal tersebut sejalan dengan apa yang terdapat dalam Peraturan Menteri Pendidikan dan Kebudayaan Republik Indonesia Nomor 81A Tahun 2013 tentang Pedoman Kegiatan Ekstrakurikuler bahwa program ekstrakurikuler merupakan program yang dinamis. Satuan pendidikan dapat menambah atau mengurangi ragam 
kegiatan ekstrakurikuler berdasarkan hasil evaluasi yang dilakukan pada setiap semester.

\section{Faktor Penunjang dan Penghambat Ekstrakurikuler MAN Model Cipasung Tasikmalaya}

Ada berbagai faktor yang menunjang terlaksananya kegiatan ekstrakurikuler di MAN Cipasung, diantaranya: Sarana prasarana, sarana prasarana yang ada di madrasah menunjang kegiatan walaupun masih ada yang perlu diperbaiki maupun ditambah. Pengadaan barang-barang selalu dilakukan setiap persemester melalui kegiatan evaluasi. Pihak madrasah selalu memfasilitasi setiap kebutuhan pelaksanaan kegiatan ekstrakurikuler. SDM, Guna mendukung peningkatan kualitas pendidik dan pemberdayaan madrasah, MAN Model Cipasung pada saat ini memiliki pendidik dan tenaga pendidik yang mempunyai keahlian tertentu dalam menunjang pelaksanaan kegiatan ekstrakurikuler bagi peserta didik. Dana, madrasah berupaya untuk memenuhi setiap kebutuhan kegiatan ekstrakurikuler, salah satunya masalah dana karena dana merupakan salah satu faktor penunjang keberhasilan kegiatan ekstrakurikuler. Dukungan pihak madrasah, dukungan guru-guru dan kepala madrasah sangat berpengaruh terhadap keberlangsungan kegiatan ekstrakurikuler di MAN Model Cipasung Tasikmalaya. Pemberian izin dari kepala madrasah dan wakamad bidang kesiswaan sangat mendukung dalam pelaksanaan kegiatan ekstrakurikuler yang ada di madrasah.

Sedangkan dalam hal faktor yang menghambat pelaksanaan kegiatan ekstrakurikuler diantaranya: Waktu, waktu yang sangat terbatas menyebabkan latihan untuk atlet tidak cukup, contoh untuk ekstrakurikuler Perisai Diri dan karate yang hanya seminggu sekali. Siswa, motivasi peserta didik untuk mengikuti kegiatan ekstrakurikuler tidak selamanya bagus. Terkadang ada saja peserta didik yang absen untuk mengikuti ekstrakurikuler karena banyaknya kegiatan yang lainnya di luar kegiatan ekstrakurikuler terlebih bagi peserta didik yang juga tinggal di pesantren sekitar Cipasung. Kegiatan ekstrakurikuler pun harus disesuaikan dengan kegiatan pengajian santri di pesantren.

\section{Hasil Manajemen Ekstrakurikuler MAN Model Cipasung Tasikmalaya}

Keberhasilan adalah sesuatu yang diharapkan, karena keberhasilan merupakan buah dari perjuangan. MAN Model Cipasung Tasikmalaya adalah salah satu lembaga pendidikan yang sudah lama berkiprah di dunia pendidikan sangat berharap para lulusannya sesuai dengan tujuan yang diharapkan. Pelaksanaan ekstrakurikuler di MAN Model Cipasung Tasikmalaya berjalan dengan baik, lancar dan sesuai dengan tujuan awal pembentukan kegiatan ekstrakurikuler, yaitu mewadahi semua bakat dan minat peserta didik agar berkembang sesuai dengan potensi yang mereka miliki. Ada berbagai faktor yang mendukung keberhasilan manajemen ekstrakurikuler di MAN Model Cipasung, antara lain: pertama, adanya izin dari Kepala Madrasah, Kesiswaan serta seluruh jajaran guru-guru, kedua, adanya peserta didik yang mempunyai bakat dan keinginan, dan ketiga anak-anak tidak menutup diri untuk membuat proses dalam kegiatan ekstrakurikuler dan mereka selalu semangat dalam menjalani proses. 
Pelaksanaan ekstrakurikuler banyak mengharumkan nama sekolah dengan banyak prestasi yang dihasilkan dari berbagai ekstrakurikuler yang diikuti oleh peserta didik. MAN Model Cipasung Tasikmalaya juga terkenal dengan sebutan "sekolah ekskul" karena banyak kegiatan ekstrakurikuler yang disediakan oleh madrasah, sehingga menarik minat masyarakat untuk menyekolahkan aanak-anak mereka ke sana.

\section{SIMPULAN}

Berdasarkan penelitian yang dilaksanakan di MAN Model Cipasung Tasikmalaya dapat ditarik kesimpulan sebagai berikut: 1) Perencanaan kegiatan ekstrakurikuler yaitu mulai dari penentuan jenis kegiatan ekstrakurikuler yang mana di MAN Model Cipasung terdapat 20 jenis ekstrakurikuler, dan ada 18 pembina sekaligus pelatih ekstrakurikuler di MAN Model Cipasung. 2) Sebelum kegiatan ekstrakurikuler dimulai, dilaksanakan apel siang terlebih dahulu khusus untuk hari Jumat. Sebelum latihan dilakukan, terlebih dahulu dikenalkan materi dan kontrak pembelajaran yang akan dilaksanakan. Pelaksanaan kegiatan ekstrakurikuler di MAN Model Cipasung berjalan lancar, yakni kebanyakan ekstrakurikuler dilaksanakan pada hari Jumat terkecuali untuk ekstrakurikuler tertentu ada tambahan latihan pada harihari biasa. Hal yang dilakukan dalam menumbuhkan partisipasi peserta didik adalah dengan cara menumbuhkan ikatan emosional kekeluargaan agar terjalin dengan baik sehingga pelaksanaan kegiatan ekstrakurikuler pun dapat terlaksana secara optimal. 3)Evaluasi kegiatan ekstrakurikuler di MAN Model Cipasung untuk menindaklanjuti program kegiatan ekstrakurikuler pada tahun ajaran berikutnya berupa penilaian dan pemantauan dari pelaksanaan ekstrakurikuler. Ada dua jenis evaluasi yang dilakukan, yakni evaluasi intern dan juga eksternal. 4) Keberhasilan yang dicapai dari manajemen ekstrakurikuler di MAN Model Cipasung yaitu, banyaknya prestasi yang diraih oleh peserta didik baik akademik maupun non akademik serta adanya peningkatan jumlah peserta didik dari tahun ke tahun karena tertarik untuk belajar di MAN Model Cipasung dengan banyaknya kegiatan ekstrakurikuler sehingga MAN Model Cipasung dikenal dengan sebutan "sekolah ekskul".

\section{DAFTAR PUSTAKA}

Asmani, J. M. (2013). Kiat Melahirkan Madrasah Unggulan. Yogyakarta: Diva Press.

Badrudin. (2014). Manajemen Peserta Didik. Bandung: Indeks.

Hasibuan, M. (2006). Manajemen:Dasar, Pengertian, dan Masalah. Jakarta: Bumi Aksara.

Hikmat. (2015). Manajemen Pendidikan, Bandung : Pustaka Setia.

Moleong, L. (2011). Metodologi Penelitian Kualitatif. Bandung: Remaja Rosdakarya.

Mulyono. (2010). Manajemen Administrasi dan Organisasi Pendidikan. Yogyakarta: Ar-Ruz Media.

Peraturan Menteri Pendidikan dan Kebudayaan Republik Indonesia Nomor 62 Tahun (2014).

Peraturan Menteri Pendidikan dan Kebudayaan Republik Indonesia Nomor 81A tahun (2013) 
Prihatin, E. (2014). Manajemen Peserta Didik. Bandung: Alfabeta.

Suryosubroto. (2009). Proses Belajar Mengajar di Sekolah. Jakarta: Rineka Cipta.

Sutikno, S. (2009). Pengelolaan Pendidikan Tinjauan Umum dan Konsep Islami. Bandung: Prospect.

Undang-Undang Sistem Pendidikan Nasional No. 20 Tahun 2003. 
Q. Y. Zakiah., I. S. Munawaroh. 